\title{
Competition and Coexistence in a Multi-species Grazing System
}

\author{
R. J. PUTMAN
}

Putman R. J., 1986: Competition and coexistence in a multi-species grazing system. Arta theriol., 31, 21: 271-291 [With 8 Tables]

In the New Forest area of southern England (approximately 37,500 hectares of mixed vegetation) populations of red deer, sika deer, fallow and roe live in sympatry with large numbers of free ranging domestic cattle and ponies. This paper examines patterns of habitat use, activity and diet of the five most abundant species (cattle, ponies, fallow, sika and roe) and presents a formal analysis of niche overlap between the various large herbivores. Considerable overlap in the use of all the different resources is revealed, although it is in regard to diet that the most significant overlap between the Forest herbivores is recorded: with overlap in forage use amongst the preferential grazers (cattle, ponies and fallow deer) consistently approaching, or in excess of $90 \%$ at all times of year. When all resources are taken into account simultaneously, in calculation of a figure for combined overlap, estimates of resource overlap fall to around $40-50 \%$. Extensive overlap in individual resource dimensions suggests considerable potential for competition between the different herbivores of this multi-species system. Although a consideration of combined resource use reduces somewhat the scale of apparent overlap, residual overlap is still high. Evidence for the existence of competition between the animals is examined and the roles of both behavioural and geographical separations in minimising such effects are explored. The paper concludes however that within the New Forest at least ponies and sika deer may be in active competition for food.

[Department of Biology, Building 44, The University, Southampton, Great Britain]

\section{INTRODUCTION}

The New Forest in Southern England is an area of approximately 37,500 ha of mixed vegetation situated within the Hampshire Basin. Some 9000 ha are occupied by towns, villages or agricultural land and a further 9000 ha are enclosed for commercial forestry; the remainder is open waste of heathland and bog $(11,000 \mathrm{ha})$ mixed woodland (4000 ha) and grassland ( $4500 \mathrm{ha})$. While much of the area is unimproved, certain sections (in total ca. $800 \mathrm{ha}$ ) of the natural arid grasslands of the Forest have been managed in different ways to increase the quality of the grazing, primarily by liming, or by ploughing, fertilising and reseeding with pasture mixes. The area is described in more detail elsewhere (Putman et al. 1981, 1982; Putman 1986; Pratt et al. 1985). The Forest was declared a Royal hunting preserve in the 11th Century and since that time has supported large populations of grazing animals. 
Five species of deer are native or naturalised within the Forest. Fallow deer (Dama dama) are widespread (numbers currently estimated at 1800), roe (Capreolus capreolus) are also widespread but less abundant (ca. 450); small populations of red deer (Cervus elaphus) and sika deer (Cervus nippon) (about 100 individuals in each case) are established more locally and muntjac (Muntiacus reevesii) may also be present in small numbers. In addition some 3,500 ponies and 2,000 domestic cattle are grazed on the 20,000 ha of unenclosed forest wastes under ancient rights of Common pasturage. The Forest offers only impoverished grazing to its various herbivores and sustains a remarkably high grazing pressure (Putman et al. 1981, 1982; Putman \& Edwards 1985).

While there is little evidence of direct interaction between the various grazers of the Forest, there are quite powerful inductive arguments suggesting that at least some of the herbivores do indirectly exert a marked influence on each other's free use of the Forest's resources. An analysis of the niche relationships of the various species was thus undertaken with respect to a number of shared resources in order to offer a more objective appraisal of potential interaction.

\section{METHODS}

During a serious of individual studies of the behaviour and ecology of the five main herbivores within in Forest between 1974 and 1984, data were collected for each species on patterns of habitat use, changes in habitat use with time (both seasonally and over the 24 hours of a day) diet and foraging behaviour. Detailed descriptions for particular species are presented elsewhere (cattle and ponies: Putman et al., 1981, 1984; Putman, 1986; Pratt et al., 1985; fallow deer: Jackson, 1974, 1977; Parfitt, 1986; roe deer: Jackson, 1980; Sharma in progress; Sika deer: Mann, 1983). Although these studies were carried out independently, in all cases data were collected in a common format; it is thus possible to make direct comparisons between the species. We may produce for each species an analysis (month by month) of the proportion of time /observations recorded in each of a variety of habitats (over the whole day, or broken down into habitat use by day and during the hours of darkness); we may produce a similar profile of percentage contribution to the diet of each of a variety of available forages; we may produce a record of the use of time by noting the proportion of the total day's activity recorded in each of 12, 2-hourly time periods. And for each resource dimension (habitat, diet, time) the list of categories recorded is exactly the same for all the species (see Tables $1-3$ ).

Within months (or groups of months selected to reflect biological seasons) overlap in the use of individual resources was calculated between all species pairs, using Pianka's (1973) symmetric index of overlap:

$$
a_{j k}=\frac{\Sigma \mathrm{p}_{1 j} \mathrm{p}_{\mathrm{ik}}}{\left[\left(\Sigma \mathrm{p}_{\mathrm{ij}}{ }^{2}\right)\left(\Sigma \mathrm{p}_{\mathrm{ik}}{ }^{2}\right)\right]^{1 / 2}}
$$

I(where $p_{i j}$ and $p_{i k}$ are the proportion made by the ith partition of a given resource 
dimension to total resource use by species $j$ and $k$ respectively. This index assumes values between 0 (total niche separation) and 1 (total overlap).

Resources habitat, food and hours of the the day were considered biologically independent; multidimensional overlap was thus calculated in each case as the product of uni-dimensional values (Pianka, 1976; May 1976).

\section{RESULTS}

Summary tables of the use of different habitat types, foodstuffs and timeperiods of the day by fallow, roe and sika deer and by free-ranging cattle and ponies are shown in Tables $1-3$.

\subsection{Habitat Use}

Patterns of habitat use by cattle and ponies in the New Forest have been described in detail by Pratt et al. 1985. Both species are preferential grazers and spend the majority of their time throughout the year on the improved grasslands of the Open Forest. Use of such open habitats is primarily during daylight: there is a pronounced movement onto the grasslands at dawn and away into communities offering more shelter, such as woodlands and gorsebrake at dusk. There is also a pronounced seasonal shift with these same cover communities being used increasingly extensively over the winter months as weather conditions deteriorate, days shorten, and grassland forage is increasingly exhausted.

Habitat use by fallow deer within the Forest has been studied by Jackson (1974) and Parfitt (1986). Both authors describe a similar pattern of use of different communities. Deciduous woodland was actively selected during early Spring (February - April) and Autumn (August October). Woodland use remained high throughout the winter in good mast years when animals remained to feed on the abundant beech mast and acorns; where mast was less abundant use of woodland declined over the winter and the deer made increasing use of more open habitats, grazing along rides and in clearings. Rides and clearings were again used heavily in midsummer. As with cattle and ponies, changes in habitat usage reflect changes in the need for shelter and in the availability of favoured foodstuffs.

No detailed information is yet available on habitat use by New Forest roe. Sika deer however, like fallow, tend to restrict their activity to the various different communities available within woodlands. Thus during the summer the majority of animals were found during the day feeding within the thicker stands of coniferous plantations; by night most of the animals moved out to those growth stages of the 


\section{Table 1}

Use of different habitats by the various large herbivores of the New Forest. Figures represent percentage of observations recorded in each habitat type in any one month. Habitats: A - improved grasslands, B - stream edges, C - acid one month. Habitats: A - implath, E - wet heath, F - bog, G - deciduous woodland, $\mathrm{H}$ - mature coniferous woodland, I - woodland rides and glades, $\mathrm{K}$ - gorse brake, L - thicket and polestage conifers, $M$ - clearfell and plantation.

\begin{tabular}{lllllllllllll}
\hline J & F & M & A & M & J & J & A & S & O & N & D \\
\hline
\end{tabular}

\begin{tabular}{rrrrrrrrrrrrr} 
A & 53 & 32 & 63 & 36 & 46 & 73 & 79 & 72 & 67 & 62 & 64 & 56 \\
B & 24 & 0 & 8 & 6 & 16 & 0 & 5 & 9 & 5 & 0 & 2 & 11 \\
C & 9 & 4 & 0 & 2 & 2 & 1 & 0 & 4 & 0 & 1 & 3 & 4 \\
D & 0 & 0 & 12 & 5 & 3 & 24 & 2 & 9 & 3 & 3 & 17 & 11 \\
E & 0 & 5 & 5 & 16 & 9 & 1 & 6 & 2 & 7 & 10 & 7 & 6 \\
F & 0 & 1 & 0 & 4 & 5 & 0 & 2 & 0 & 2 & 0 & 0 & 11 \\
G & 0 & 39 & 10 & 10 & 16 & 0 & 9 & 2 & 8 & 24 & 2 & 0 \\
H & 1 & 0 & 1 & 0 & 0 & 0 & 0 & 1 & 6 & 0 & 0 & 0 \\
I & 0 & 18 & 0 & 1 & 0 & 1 & 1 & 0 & 0 & 1 & 5 & 0 \\
K & 13 & 0 & 0 & 1 & 2 & 1 & 1 & 0 & 2 & 0 & 0 & 0 \\
\hline
\end{tabular}

\begin{tabular}{lrrrrrrrrrrrr}
\multicolumn{10}{c}{ Ponies } \\
A & 39 & 28 & 55 & 49 & 34 & 34 & 41 & 44 & 31 & 46 & 43 & 49 \\
B & 5 & 6 & 12 & 9 & 19 & 12 & 13 & 9 & 9 & 11 & 13 & 3 \\
C & 3 & 9 & 1 & 10 & 3 & 4 & 6 & 4 & 3 & 2 & 3 & 2 \\
D & 4 & 10 & 4 & 3 & 14 & 11 & 7 & 7 & 12 & 11 & 18 & 11 \\
E & 15 & 9 & 7 & 7 & 14 & 14 & 13 & 13 & 13 & 7 & 5 & 8 \\
F & 2 & 5 & 7 & 9 & 9 & 12 & 8 & 10 & 12 & 4 & 4 & 4 \\
G & 20 & 12 & 12 & 10 & 6 & 6 & 6 & 9 & 13 & 13 & 7 & 6 \\
H & 0 & 0 & 0 & 0 & 1 & 3 & 2 & 1 & 2 & 0 & 0 & 2 \\
I & 0 & 4 & 0 & 2 & 0 & 2 & 3 & 2 & 6 & 2 & 4 & 5 \\
K & 12 & 16 & 2 & 1 & 0 & 1 & 0 & 0 & 0 & 3 & 3 & 11 \\
\hline
\end{tabular}

\begin{tabular}{|c|c|c|c|c|c|c|c|c|c|c|c|c|}
\hline & & & & & & allow & eer & & & & & \\
\hline A & 0 & 0 & 0 & 0 & 0 & 0 & 0 & 0 & 0 & 0 & 0 & 0 \\
\hline B & 0 & 0 & 0 & 0 & 0 & 0 & 0 & 0 & 0 & 0 & 0 & 0 \\
\hline C & 9 & 4 & 2 & 0 & 2 & 9 & 2 & 2 & 1 & 2 & 9 & 9 \\
\hline D & 0 & 0 & 0 & 0 & 0 & 0 & 0 & 0 & 0 & 0 & 0 & 0 \\
\hline E & 0 & 0 & 0 & 0 & 0 & 0 & 0 & 0 & 0 & 0 & 0 & 0 \\
\hline $\mathrm{F}$ & 0 & 0 & 0 & 0 & 0 & 0 & 0 & 0 & 0 & $\theta$ & 0 & 0 \\
\hline G & 13 & 49 & 58 & 43 & 16 & 20 & 6 & 46 & 46 & 40 & 20 & 26 \\
\hline $\mathrm{H}$ & 35 & 38 & 8 & 32 & 38 & 33 & 23 & 28 & 28 & 26 & 19 & 23 \\
\hline I & 31 & 25 & 19 & 20 & 30 & 30 & 59 & 26 & 26 & 28 & 42 & 38 \\
\hline $\mathrm{K}$ & 0 & 0 & 0 & 0 & $\theta$ & 0 & 0 & 0 & 0 & 0 & 0 & 0 \\
\hline L & 0 & 0 & 0 & 0 & 0 & 0 & 0 & 0 & 0 & 0 & 0 & 0 \\
\hline M & 0 & 0 & 0 & 0 & 0 & 0 & 0 & 0 & 0 & 0 & 0 & 0 \\
\hline
\end{tabular}

\begin{tabular}{lrrrrrrrrrrrrr}
\multicolumn{10}{c}{ Sika deer } \\
A & \multicolumn{1}{c}{} & 0 & 0 & 0 & 0 & 0 & 0 & 0 & 0 & 0 & 0 & 0 & 0 \\
B & 0 & 0 & 0 & 0 & 0 & 0 & 0 & 0 & 0 & 0 & 0 & 0 \\
C & 0 & 0 & 0 & 0 & 0 & 0 & 0 & 0 & 0 & 0 & 0 & 0 \\
D & 0 & 0 & 0 & 0 & 0 & 0 & 0 & 0 & 1 & 1 & 0 & 0 \\
E & 0 & 0 & 0 & 0 & 0 & 0 & 0 & 0 & 0 & 0 & 0 & 0 \\
F & 0 & 0 & 0 & 0 & 0 & 0 & 0 & 0 & 0 & 0 & 0 & 0 \\
G & 50 & 52 & 50 & 55 & 48 & 31 & 27 & 32 & 35 & 56 & 74 & 62 \\
H & 0 & 0 & 0 & 0 & 0 & 0 & 0 & 0 & 0 & 0 & 0 & 0 \\
I & 24 & 27 & 26 & 13 & 23 & 29 & 30 & 27 & 26 & 18 & 13 & 21 \\
K & 0 & 0 & 0 & 0 & 0 & 0 & 0 & 0 & 0 & 0 & 0 & 0 \\
L & 20 & 17 & 13 & 16 & 16 & 23 & 20 & 20 & 12 & 18 & 10 & 11 \\
M & 6 & 4 & 11 & 16 & 13 & 17 & 23 & 21 & 26 & 7 & 3 & 6 \\
\hline
\end{tabular}


Table 2

Diet of the different herbivores in the New Forest. Figures are percentage contribution to the diet made by each forage category. A - Molinia, B - other grasses, C - herbs, D - conifers, E - holly, F - other broadleaves, G - heather, $\mathrm{H}$ - gorse, I - fruits, $\mathrm{K}$ - other.

\begin{tabular}{|c|c|c|c|c|c|c|c|c|c|c|c|c|}
\hline & J & F & M & A & M & $\mathrm{J}$ & $\mathbf{J}$ & A & $\mathrm{S}$ & o & $\mathrm{N}$ & D \\
\hline \multicolumn{13}{|c|}{ Cattle } \\
\hline $\begin{array}{l}\mathrm{A} \\
\mathrm{B}\end{array}$ & 75 & 67 & 71 & $\begin{array}{r}0 \\
80\end{array}$ & $\begin{array}{r}0 \\
80\end{array}$ & $\begin{array}{r}0 \\
83\end{array}$ & 1 & 0 & 1 & 1 & 1 & 1 \\
\hline C & 0 & 0 & 0 & 0 & 1 & 0 & $\begin{array}{r}81 \\
0\end{array}$ & 70 & $\begin{array}{r}65 \\
1\end{array}$ & 69 & 69 & 65 \\
\hline D & 0 & 0 & 0 & 0 & 0 & 0 & 0 & $\begin{array}{l}0 \\
0\end{array}$ & $\begin{array}{l}1 \\
0\end{array}$ & $\begin{array}{l}1 \\
0\end{array}$ & $\begin{array}{l}0 \\
0\end{array}$ & $\begin{array}{l}1 \\
0\end{array}$ \\
\hline $\mathbf{E}$ & 0 & 0 & 0 & 0 & 0 & 0 & 0 & 0 & 0 & 0 & 0 & 0 \\
\hline F & 1 & 1 & 1 & 1 & 0 & 0 & 0 & 1 & 2 & 1 & 2 & 1 \\
\hline G & 21 & 27 & 24 & 9 & 14 & 12 & 13 & 18 & 23 & 19 & 21 & 22 \\
\hline $\mathrm{H}$ & 0 & 0 & 0 & 0 & 0 & 0 & 0 & 0 & 0 & 0 & 0 & 0 \\
\hline I & 0 & 0 & 0 & 0 & 0 & 0 & 0 & 0 & 0 & 0 & 0 & 0 \\
\hline K & 3 & 5 & 4 & 10 & 5 & 5 & 5 & 11 & 8 & 9 & 7 & 10 \\
\hline \multicolumn{13}{|c|}{ Ponies } \\
\hline A & 3 & 1 & 0 & 0 & 17 & 22 & 24 & 17 & 7 & 3 & 2 & 2 \\
\hline B & 46 & 36 & 43 & 65 & 73 & 68 & 68 & 70 & 76 & 76 & 67 & 49 \\
\hline C & 0 & 0 & 0 & 0 & 0 & 0 & 4 & 0 & 0 & 0 & 0 & 0 \\
\hline D & 0 & 0 & 0 & 0 & 0 & 0 & 0 & 0 & 0 & 0 & 0 & 0 \\
\hline $\mathrm{E}$ & 20 & 26 & 25 & 13 & 0 & 0 & 0 & 0 & 0 & 3 & 11 & 13 \\
\hline $\bar{F}$ & 0 & 0 & 0 & 0 & 2 & 1 & 0 & 1 & 1 & 0 & 0 & 0 \\
\hline G & 7 & 7 & 5 & 3 & 1 & 1 & 1 & 1 & 2 & 3 & 5 & 10 \\
\hline $\mathrm{H}$ & 12 & 13 & 10 & 1 & 0 & 0 & 0 & 0 & 0 & 1 & 3 & 10 \\
\hline I & 0 & 0 & 0 & 0 & 0 & 0 & 0 & 0 & 0 & 0 & 0 & 0 \\
\hline $\mathrm{K}$ & 12 & 17 & 17 & 18 & 7 & 8 & 7 & 11 & 14 & 14 & 12 & 16 \\
\hline \multicolumn{13}{|c|}{ Fallow deer } \\
\hline B & 21 & 25 & 59 & 67 & 63 & 63 & 63 & 57 & 58 & 33 & 25 & 21 \\
\hline C & 1 & 1 & 1 & 6 & 6 & 6 & 6 & 12 & 7 & 2 & 2 & 1 \\
\hline D & 14 & 14 & 7 & 1 & 0 & 0 & 0 & 0 & 0 & 0 & 8 & 17 \\
\hline E & 12 & 17 & 9 & 7 & 4 & 4 & 4 & 3 & 1 & 0 & 2 & 7 \\
\hline $\mathrm{F}$ & 26 & 12 & 3 & 9 & 21 & 21 & 21 & 24 & 15 & 14 & 26 & 16 \\
\hline G & 16 & 24 & 16 & 3 & 4 & 4 & 4 & 3 & 2 & 1 & 8 & 16 \\
\hline $\mathrm{H}$ & 0 & 0 & 0 & 0 & 0 & 0 & 0 & 0 & 0 & 0 & 0 & 0 \\
\hline $\mathbf{I}$ & 2 & 0 & 0 & 0 & 0 & 0 & 0 & 0 & 14 & 41 & 22 & 15 \\
\hline K & 8 & 7 & 5 & 7 & 2 & 2 & 2 & 1 & 3 & 9 & 7 & 7 \\
\hline \multicolumn{13}{|c|}{ Sika deer } \\
\hline B & 25 & 25 & 22 & 39 & 38 & 40 & 39 & 50 & 44 & 31 & 28 & 27 \\
\hline C & 0 & 0 & 0 & 0 & 0 & 0 & 0 & 0 & 0 & 0 & 0 & 0 \\
\hline D & 20 & 19 & 23 & 13 & 2 & 0 & 0 & 1 & 0 & 6 & 8 & 16 \\
\hline $\mathrm{E}$ & 1 & 3 & 1 & 1 & 1 & 1 & 1 & 1 & 2 & 2 & 1 & 1 \\
\hline $\mathbf{F}$ & 11 & 11 & 10 & 13 & 14 & 14 & 16 & 10 & 19 & 25 & 14 & 14 \\
\hline G & 24 & 23 & 30 & 23 & 35 & 37 & 35 & 29 & 27 & 23 & 24 & 25 \\
\hline $\mathrm{H}$ & 7 & 14 & 8 & 7 & 6 & 5 & 6 & 6 & 7 & 4 & 7 & 5 \\
\hline I & 6 & 4 & 2 & 0 & 0 & 0 & 0 & 0 & 0 & 6 & 14 & 9 \\
\hline $\mathrm{K}$ & 6 & 1 & 4 & 4 & 4 & 3 & 3 & 3 & 1 & 3 & 4 & 3 \\
\hline \multicolumn{13}{|c|}{ Roe deer } \\
\hline B & 4 & 5 & 5 & 10 & 7 & 8 & 8 & 8 & 8 & 9 & 10 & 4 \\
\hline $\bar{C}$ & 5 & 2 & 2 & 30 & 16 & 16 & 16 & 17 & 17 & 4 & 4 & 6 \\
\hline D & 33 & 22 & 22 & 5 & 1 & 8 & 0 & 0 & 0 & 12 & 12 & 13 \\
\hline $\bar{E}$ & 0 & 2 & 0 & 0 & 0 & 14 & 1 & 0 & 0 & 0 & 0 & 0 \\
\hline$\vec{F}$ & 45 & 52 & 52 & 41 & 71 & 50 & 58 & 58 & 55 & 54 & 53 & 50 \\
\hline G & 6 & 14 & 14 & 14 & 5 & 4 & 7 & 7 & 5 & 5 & 4 & 7 \\
\hline $\mathrm{H}$ & 0 & 0 & 0 & 0 & 0 & 0 & 0 & 0 & 0 & 0 & 0 & 0 \\
\hline I & 1 & 1 & 1 & 0 & 0 & 0 & 0 & 0 & 8 & 8 & 17 & 7 \\
\hline $\mathrm{K}$ & 6 & 2 & 3 & 0 & 0 & 0 & 10 & 10 & 7 & 8 & 0 & 13 \\
\hline
\end{tabular}


coniferous blocks which are more open - or out into the Forest oakwoods. In the autumn, increasing use is made of deciduous woodlands to exploit the abundant mast, but in late autumn and winter as the acorn crop becomes exhausted the animals start feeding more extensively on coniferous browse and Calluna heath (Table 2). These foodstuffs are available in a variety of habitats; the animals still spend most of their time within the oakwoods, but may forage out into prethicket conifer stands or open heathland (Mann 1983).

\subsection{Diet}

With the exception of the roe deer, all species studied are preferential grazers (Table 2). The diet of New Forest cattle remains remarkably similar throughout the year, virtually constant in terms of species composition, varying only in minor changes in relative proportions of those components. Some $70-80 \%$ of the diet is of grass; heather provides the bulk of the remaining forage (between $15 \%$ and $25 \%$ at different times of year). By contrast pony diet shows marked seasonal change. Summer diet (May - August) like that of the cattle, is predominantly of grass, which comprises between $80 \%$ and $90 \%$ of the diet at this time. In contrast with cattle, the ponies feed extensively on the grass Molinia caerulea at this period: Molinia makes up nearly 20\% of the total diet, $22 \%$ of the total grass intake at this time. During September and October, Molinia intake declines, to only 3\% (Molinia is a deciduous grass and becomes sere and unpalatable at this time); total grass percentage however remains relatively constant at ca. $80 \%$, with a greatly increased intake of Agrostis setacea balancing the Molinia decline. As autumn changes into winter, the percentage of grass in the diet declines, to $50 \%$ of total intake. Correspondingly, there is a progressive increase, from October right through until February/March, of the amount of gorse and tree leaves (mostly holly, Ilex aquifolium) which are taken. The proportion of moss in the diet also increases over this period and heather intake, too, is increased in winter (Putman, 1986).

The diet of Fallow deer within the New Forest has been studied in detail by Jackson $(1974,1977)$ and more recently by Parfitt (1986). Results are highly complementary and both authors show that through most of the year the deer are primarily grazers. Throughout the growing season - from March to September, grasses form the principal food (comprising in the region of $60 \%$ of total food intake), with herbs and broadleaf browse also making a significant contribution. Acorns and mast are a characteristic food throughout autumn and early winter, although their importance in the diet varies from year to year with variations in the mast crop. Other major foods through autumn and 
winter - on which the deer rely more heavily when the year's mast: is exhausted - are bramble, holly, ivy, heather, and browse from felled conifers. Even at this time however, grass still makes up morethan $20 \%$ of the diet; it is evident from this that the deer are preferential grazers throughout the year, and take increasing amounts of browse over autumn and winter merely to compensate for lack of graze materials outside the growing season.

Mann (1983) used both ruminal and faecal analyses in complement in derivation of a picture of diet for sika deer in a number of locations: throughout Britain. Diet of the deer in most areas (throughout Scotland, and coniferous forests in Dorset) was shown to be relatively constant throughout the year - with a high intake of grass $(30-40 \%)$ and Calluna $(40-50 \%)$ in all seasons. A variety of other dietary components. contribute the remaining part of the diet, but no single item comprised more than $5-6 \%$ at any time. Grasses consumed were principally Molinia caerulea (50\% of all grass), Agrostis setacea and A. tenuis (Mann 1983). By comparison diet of the New Forest sika appears somewhat unusual, for in the New Forest the deer take considerable quantities of coniferous and deciduous browse, particularly in the winter when browse may comprise up to $25 \%$ of total dietary intake. (Horwood \& Masters, 1970, Mann 1983).

In Spring and Summer, New Forest sika do feed extensively on grasses: $(30-40 \%$ of the diet) and Calluna $(30-35 \%)$ as do Dorset and Scottish populations. But the diet is far more varied and includes significant amounts of other forages: forbs, deciduous tree leaves, gorse and coniferous browse. In autumn only $25 \%$ of the diet is formed of heather and grass, the remainder composed of pine needles, gorse, holly and mast. Winter sees an increase in the intake of coniferous material and a corresponding decline in intake of deciduous browse and forbs; at this time less than $20 \%$ of the diet is made up of grasses.

Amongst the New Forest herbivores, roe deer rely most heavily on browse materials. Jackson's analyses of roe diet (Jackson 1980) showed that young browse material: bramble, rose and new growth of deciduous woodland trees and dwarf shrubs, formed the bulk of the diet throughout the year. Bramble and rose together formed between $25 \%$ and $45 \%$ of the diet throughout and comprised the largest food fraction in all months except January and April. From January to March, foliage from felled conifers, or from young plantations, Calluna and ivy were major foods with lesser amounts of grasses, herbs and fungi. Over the summer, growing season, herbs and grasses became more important, and new growth of deciduous trees and shrubs were also favoured. (Although browse from these plants was seen in the ingesta all through 
the year, amounts present from October till March were minimal; from April to September however, such browse formed from between $10 \%$ $30 \%$ of the diet). During the autumn, acorns were a characteristic food, when available; fruit and nuts formed up to $15 \%$ of the diet from September through till mid-winter.

\subsection{Activity Patterns}

Detailed information of diurnal changes in activity is only available for 3 of the species considered here (Table 3). Ponies are clearly most active throughout the year during hours of daylight. Cattle too are essentially most active during the day, although there is perhaps a tendency towards peaks in activity around dawn and dusk in late Spring (February - May). By contrast sika deer in the New Forest, while they may be active at any time during the 24 hour period, show marked peaks of activity at dawn and dusk in all seasons; the same essentially crepuscular pattern is also shown by fallow, although complete data are not presented here.

\subsection{Overlap in Resource Use}

Indices of overlap between the various species in the use of each resource were calculated for each month. For simplicity however, results presented here (Tables 4-6) offer summaries within four main seasons of Winter (December - February), Spring (March - May), Summer (June - August), and Autumn (September - November). Seasonal calculations using other groupings of months with Winter as November - February, Summer: May - August, and spring and Autumn, March/ April and September/October respectively did not produce results significantly different from those reported here.

Throughout the year there appears relatively high overlap between cattle and ponies with respect to use of habitat, $(\alpha=0.78$ overall), although this is at its highest in Spring and Summer months when both species are making extensive use of the favoured grasslands. Sika and fallow deer also show some overlap in habitat use, through spring summer and autumn ( $\alpha=0.63$ for the year as a whole). However it is in regard to diet that the most significant overlaps in resource use between the Forest herbivores are recorded (Table 5). With the exception of the roe deer, whose browsing habit results in relatively low overlap with any of the other, primarily grazing, species, all other species show considerable overlaps in diet.

Cattle and ponies are seen to have an overlap of approximately 0.9 or above in all seasons, despite the high intake of Molinia by ponies over 


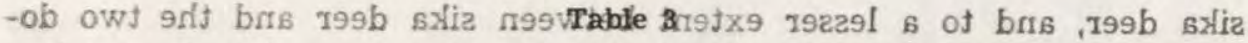
Activity patterns of cattle, ponfes and sika deer withfin the New Forest? (ma months)

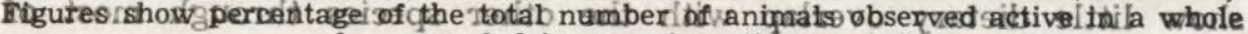

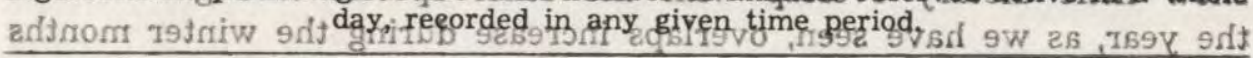

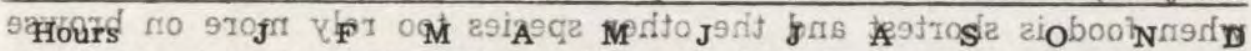

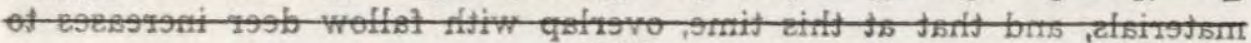

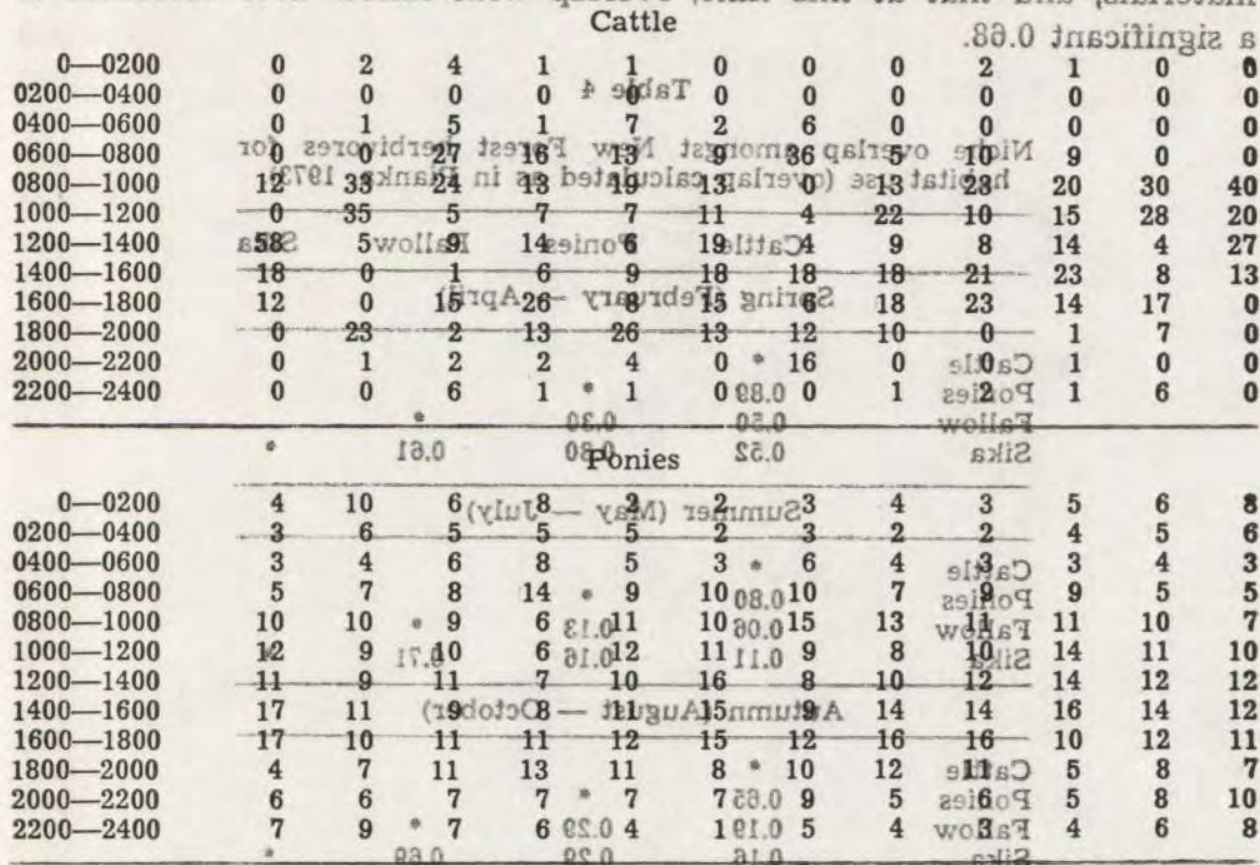

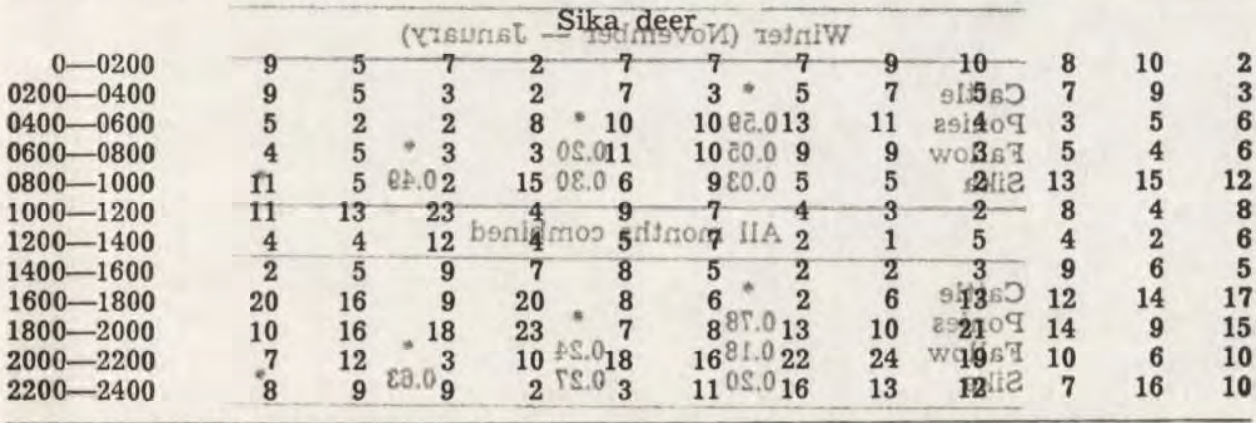

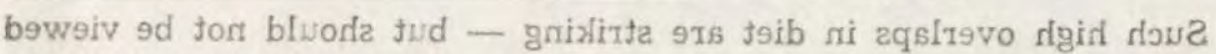

the ISpring iand Summer (a forage not exploited at all coy Forest leattre) and despite theip increased intake of browse such as hollyi and gorse during the winter moriths, again foodstuffs not generally taken byceattle.

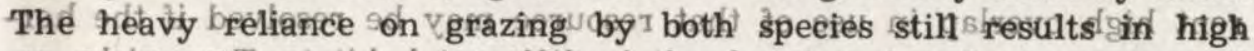

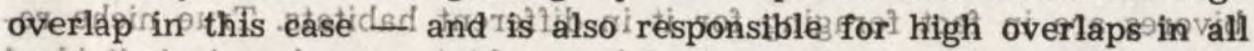
seasons netween I fallow deer, cattle and ponies, betweens fallow and 
sika deer, and to a lesser extent between sika deer and the two domestic species. In addition we should note that even though roe deer show little dietary overlap with the other species through most of the year, as we have seen, overlaps increase during the winter months when food is shortest and the other species too rely more on browse materials, and that at this time, overlap with fallow deer increases to a significant 0.68 .

Table 4

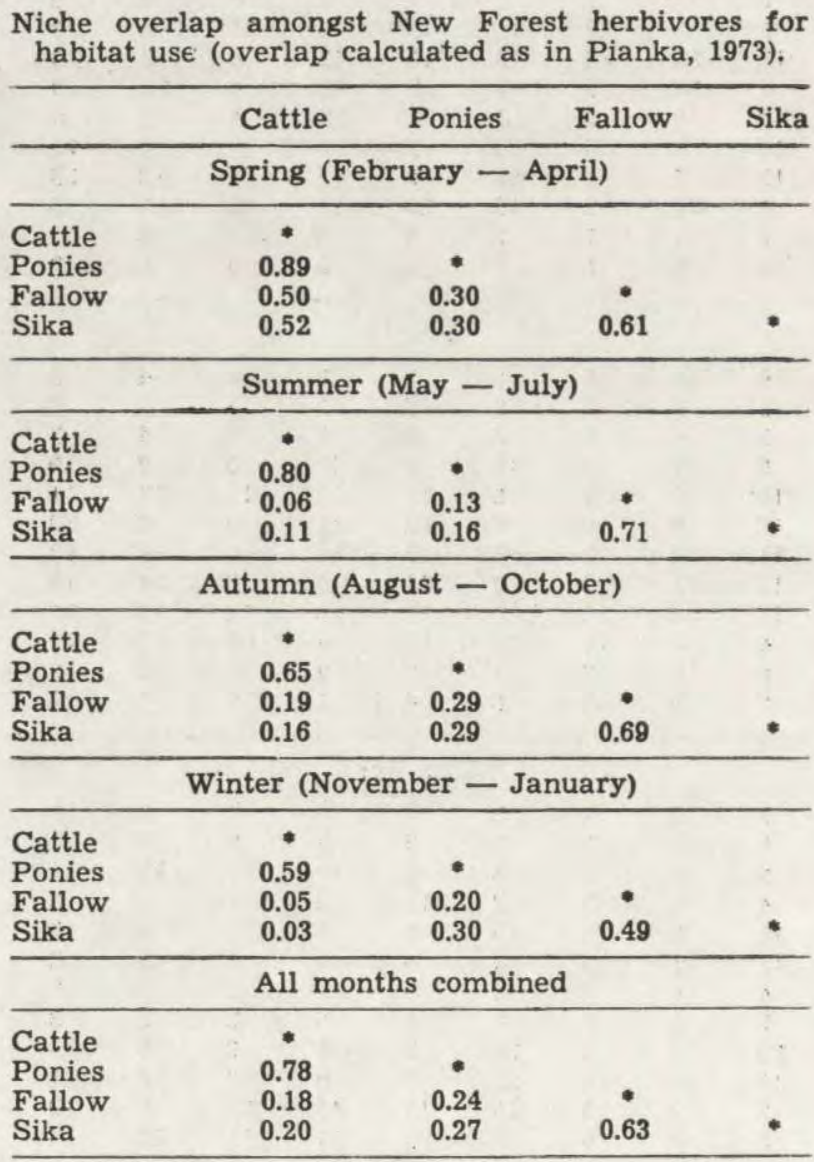

Such high overlaps in diet are striking - but should not be viewed in isolation. Apparent overlap in a single resource dimension may be far lower in practice when other dimensions of the niche are taken into account. The same foodstuff may grow in a variety of habitats: apparent high overlap in use of that resource may be resolved if the herbivores are in fact foraging for it in different habitats. True niche relationships are thus best examined by combining overlaps in individual 
resource dimensions into a multidimensional whole. Table 6 shows combined niche overlap between the five herbivore species when all dimensions - use of habitat, diet, and use of time - are taken into consideration at once. (NB for roe deer, only dietary overlap is available). Combined overlaps can be seen to be significantly reduced, with differences in use of habitat or time of day compensating for the high dietary overlaps recorded above. Niche overlaps fall to around $0.4-0.5$;

Table 5

\begin{tabular}{|c|c|c|c|c|c|}
\hline & Cattle & Ponies & Fallow & Sika & Roe \\
\hline \multicolumn{6}{|c|}{ Spring (February - April) } \\
\hline Cattle & - & & & & \\
\hline Ponies & 0.87 & * & & & \\
\hline Fallow & 0.96 & 0.92 & $*$ & & \\
\hline Sika & 0.77 & 0.66 & 0.81 & - & \\
\hline Roe & 0.20 & 0.14 & 0.39 & 0.53 & • \\
\hline \multicolumn{6}{|c|}{ Summer (May - July) } \\
\hline Cattle & - & & & & \\
\hline Ponies & 0.95 & - & & & \\
\hline Fallow & 0.94 & 0.94 & - & & \\
\hline Sika & 0.80 & 0.72 & 0.78 & - & \\
\hline Roe & 0.14 & 0.14 & 0.35 & 0.32 & * \\
\hline \multicolumn{6}{|c|}{ Autumn (August - October) } \\
\hline Cattle & $\cdot$ & & & & \\
\hline Ponies & 0.96 & $*$ & & & \\
\hline Fallow & 0.86 & 0.88 & * & & \\
\hline Sika & 0.90 & 0.80 & 0.79 & * & \\
\hline Roe & 0.20 & 0.17 & 0.45 & 0.31 & * \\
\hline \multicolumn{6}{|c|}{ Winter (November - January) } \\
\hline Cattle & $*$ & & & & \\
\hline Ponies & 0.93 & - & & & \\
\hline Fallow & 0.65 & 0.63 & * & & \\
\hline Sika & 0.77 & 0.69 & 0.87 & - & \\
\hline Roe & 0.16 & 0.14 & 0.68 & 0.37 & - \\
\hline
\end{tabular}

All months combined

\begin{tabular}{lcccc}
\hline Cattle & $*$ & & & \\
Ponies & 0.96 & $*$ & & \\
Fallow & 0.92 & 0.91 & $*$ & \\
Sika & 0.84 & 0.75 & 0.84 & $*$ \\
Roe & 0.18 & 0.15 & 0.43 & 0.37 \\
\hline
\end{tabular}


the bigheste overlap remaining being between cattle and iponies in inspring

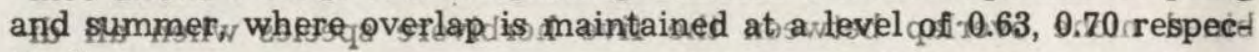

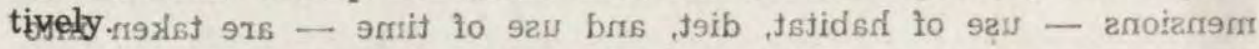

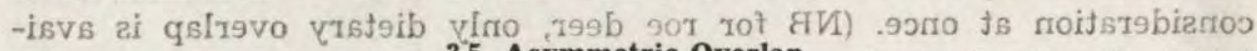

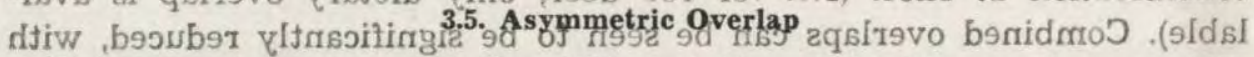

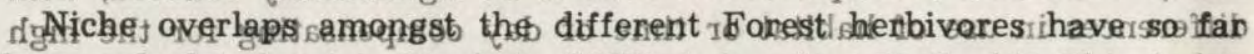

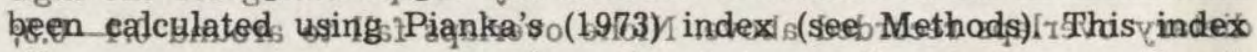
offers a symmetric measure of overlap between the species considered.

\section{Tabiles}

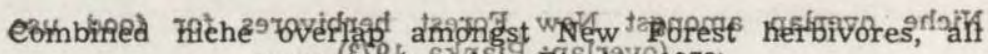
resources (overilap. Piantid, 1973).

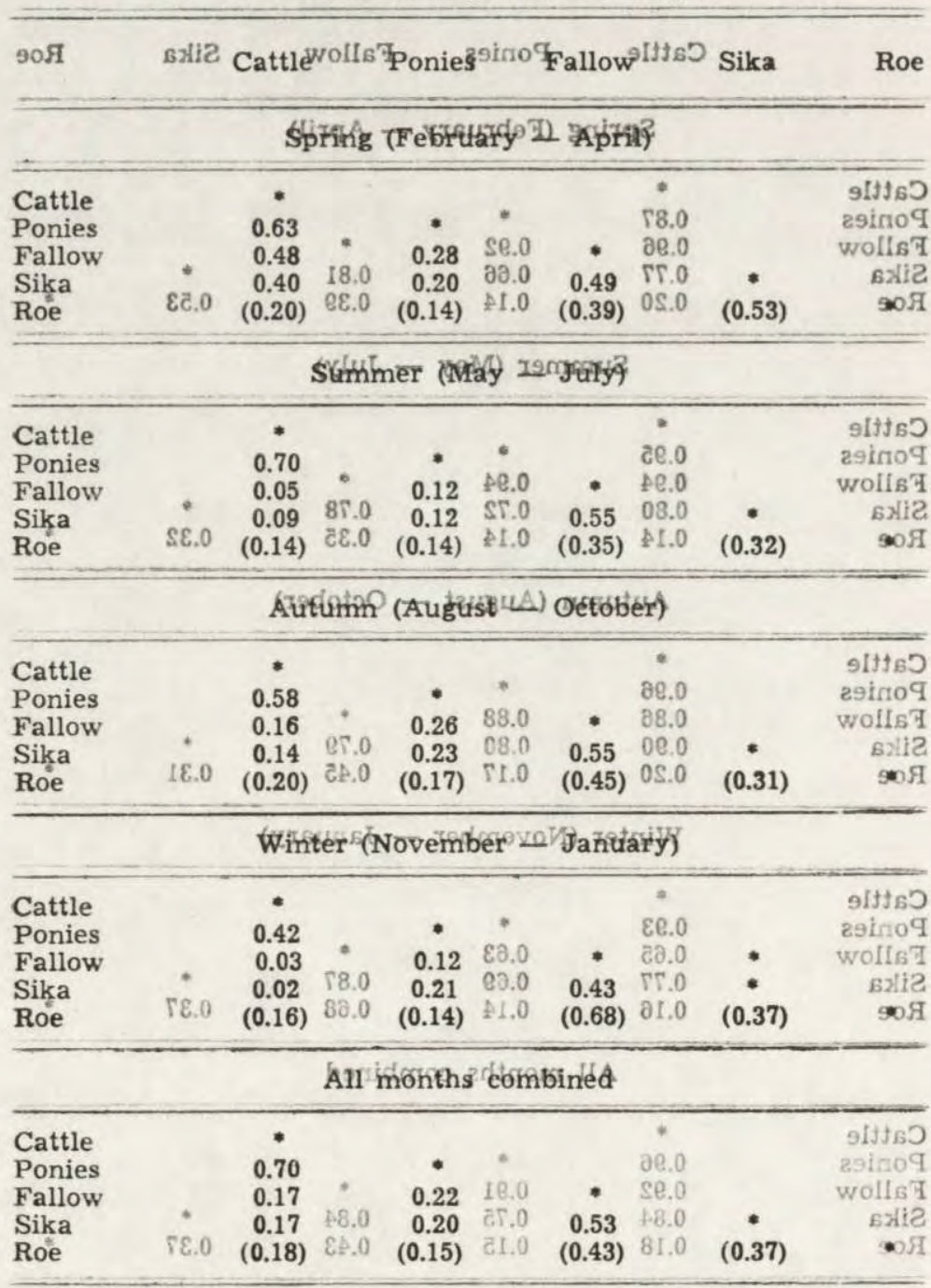




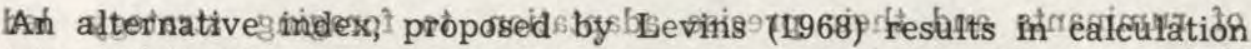
of ovierlapis betwreen speciest which bre not symmetrical (that is overlap

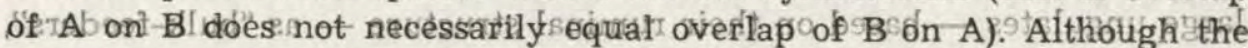

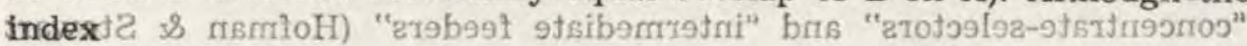

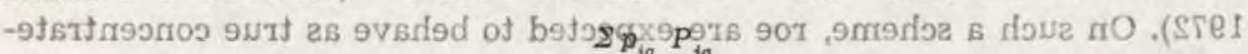

$$
a_{i j}=\frac{\sum p_{i a} p_{j a}}{\sum \sum_{i d s}^{2}}
$$

is more difficult to interpret, since values are not restricted to the range

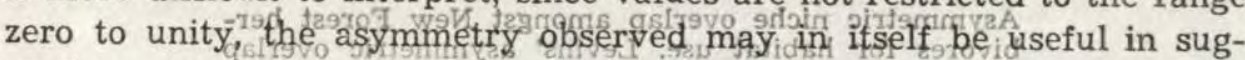
gesting which of a pair of specieso is mostaffected by a given overlap in resource use (Slobodchikoff \& Schutz 1980). Accordingly asymmetric indices of niche overlap were ${ }^{2}$ calculated in ${ }^{\top}$ the present study (Tables $7,8)$.

These figures suggest that in use of habitat overlap with cattle has a greater effect on pomies thansvice versta. In terms lof ofood use, the high overlap fecorded, between gattle ahd ponies ind alf seasons also tends to have more of an affecto on the ponies than on the cattle; cattle also have the dominating effect in interactions with fallow deer, but that overlap noted between fallow and sika is nearly symmetrical. The direction of sthese interactions as omaintained in indices 'calculated for

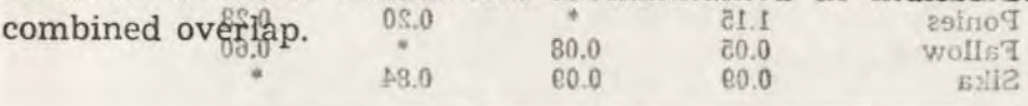

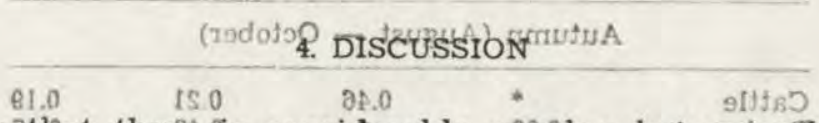

It is clearithat thefe. is considerable overlap between the five main herbivores of the New Forest in their use of a number of $f_{\text {f }}$ thesources, and clearly there is a real potential for competition between them. Figures calculated for overlap in terms of diet for ${ }^{7}$ example reveal surprisingly high overlaps between cattle and ponies. Such high overlap is unexpected because, although both species are ${ }^{0}$ preferential ograzers, cattle as noted show, little variation in their diefary composition throughout the year yet ponies take-significant quantities of browse during winter and early spring (a forage type not much exploited by cattle). Further Molinia caerulea is a very important component of pony diet through the summer (between May and August this species may comprise 20\% of the total difet); yet" gattle were never observed to take significant quantities of this species. Overlap with the grazing species of deer (fallow and sika) is also high. Only the roe deer stands out as distingt in its dietary requirements b9 Roe havef long been known as as highly I selective feegders who pluck small and highly-nutritious morsels from a wide variety of plant species: Recognition of structural and a natomical differences in the got strueture 
of ruminants and their precise adaptation to foraging strategy led Hofmann and co-workers to draw up a comprehensive classification of large ungulates - based on their ruminal structure - as "bulk-feeders", "concentrate-selectors" and "intermediate feeders" (Hofman \& Stewart 1972). On such a scheme, roe are expected to behave as true concentrate-

Table 7

Asymmetric niche overlap amongst New Forest herbivores for habitat use. Levins' asymmetric overlap (Levins, 1968): effect of column upon row.

\begin{tabular}{|c|c|c|c|c|}
\hline & Cattle & Ponies & Fallow & Sika \\
\hline \multicolumn{5}{|c|}{ Spring (February - April) } \\
\hline Cattle & $*$ & 0.81 & 0.80 & 0.88 \\
\hline Ponies & 0.98 & $*$ & 0.53 & 0.56 \\
\hline Fallow & 0.31 & 0.17 & $*$ & 0.67 \\
\hline Sika & 0.31 & 0.16 & 0.56 & $*$ \\
\hline \multicolumn{5}{|c|}{ Summer (May - July) } \\
\hline Cattle & * & 0.56 & 0.06 & 0.13 \\
\hline Ponies & 1.15 & $*$ & 0.20 & 0.28 \\
\hline Fallow & 0.05 & 0.08 & $*$ & 0.60 \\
\hline Sika & 0.09 & 0.09 & 0.84 & $*$ \\
\hline \multicolumn{5}{|c|}{ Autumn (August - October) } \\
\hline Cattle & * & 0.46 & 0.21 & 0.19 \\
\hline Ponies & 0.92 & $*$ & 0.48 & 0.47 \\
\hline Fallow & 0.17 & 0.19 & $*$ & 0.58 \\
\hline Sika & 0.14 & 0.17 & 0.82 & $*$ \\
\hline
\end{tabular}

Winter (November - January)

\begin{tabular}{lcccc}
\hline Cattle & $*$ & 0.44 & 0.05 & 0.04 \\
Ponies & 0.78 & $*$ & 0.27 & 0.55 \\
Fallow & 0.05 & 0.15 & $*$ & 0.59 \\
Sika & 0.19 & 0.17 & 0.41 & $*$ \\
\hline \multicolumn{5}{c}{ All months combined } \\
\hline Cattle & $*$ & 0.60 & 0.20 & 0.28 \\
Ponies & 1.04 & $*$ & 0.37 & 0.49 \\
Fallow & 0.15 & 0.16 & $*$ & 0.62 \\
Sika & 0.15 & 0.15 & 0.64 & $*$ \\
\hline
\end{tabular}

-selectors, fallow as bulk feeders, and sika as just more "intermeliate" than the pure grazers (Hofmann et al. 1976; Hofmann 1982); predictions amply borne out by the ecological analyses of feeding style presented here.

Despite these overall differences in diet and feeding "strategy" be:ween 
the three deer species however, many types of forage are taken by all three species, and there is in fact considerable dietary overlap at some times of year. In winter in particular when food is restricted both in quantity and variety, overlap between roe deer and fallow

Table 8

Asymmetric niche overlap amongst New Forest herbivores for food use. Levins' asymmetric overlap (Levins, 1968): effect of column upon row.

\begin{tabular}{|c|c|c|c|c|c|}
\hline 1 & Cattle & Ponies & Fallow & Sika & Roe \\
\hline \multicolumn{6}{|c|}{ Spring (February - April) } \\
\hline Cattle & $*$ & 0.65 & 0.70 & 0.46 & 0.14 \\
\hline Ponies & 1.17 & $*$ & 0.90 & 0.52 & 0.14 \\
\hline Fallow & 1.32 & 0.94 & * & 0.67 & 0.28 \\
\hline Sika & 1.29 & 0.82 & 0.98 & $*$ & 0.46 \\
\hline Roe & 0.28 & 0.15 & 0.54 & 0.60 & $*$ \\
\hline \multicolumn{6}{|c|}{ Summer (May - July) } \\
\hline Cattle & * & 0.84 & 0.76 & 0.53 & 0.10 \\
\hline Ponies & 1.07 & $*$ & 0.70 & 0.44 & 0.10 \\
\hline Fallow & 1.16 & 1.28 & * & 0.66 & 0.24 \\
\hline Sika & 1.20 & 1.18 & 0.92 & $*$ & 0.26 \\
\hline Roe & 0.18 & 0.20 & 0.50 & 0.39 & $*$ \\
\hline \multicolumn{6}{|c|}{ Autumn (August - October) } \\
\hline Cattle & $*$ & 1.01 & 0.67 & 0.66 & 0.16 \\
\hline Ponies & 0.91 & $*$ & 0.59 & 0.50 & 0.12 \\
\hline Fallow & 1.11 & 1.32 & $*$ & 0.76 & 0.37 \\
\hline Sika & 1.23 & 1.27 & 0.81 & * & 0.26 \\
\hline Roe & 0.24 & 0.24 & 0.54 & 0.36 & $*$ \\
\hline \multicolumn{6}{|c|}{ Winter (November - January) } \\
\hline Cattle & $*$ & 0.75 & 0.36 & 0.45 & 0.12 \\
\hline Ponies & 1.17 & $*$ & 0.42 & 0.49 & 0.13 \\
\hline Fallow & 1.19 & 0.95 & $*$ & 1.02 & 0.86 \\
\hline Sika & 1.33 & 0.98 & 0.73 & * & 0.40 \\
\hline Roe & 0.22 & 0.15 & 0.54 & 0.35 & * \\
\hline \multicolumn{6}{|c|}{ All months combined } \\
\hline Cattle & - & 0.81 & 0.62 & 0.53 & 0.13 \\
\hline Ponies & 1.13 & $*$ & 0.66 & 0.50 & 0.12 \\
\hline Fallow & 1.35 & 1.26 & $*$ & 0.81 & 0.36 \\
\hline Sika & 1.33 & 1.12 & 0.88 & $*$ & 0.32 \\
\hline Roe & 0.23 & 0.19 & 0.52 & 0.42 & * \\
\hline
\end{tabular}

increases significantly. Jackson (1980) also noted that diets of roe and fallow deer within the Forest showed greatest overlap in winter and early spring. Concentrating on this period of the year on the assumption that if there is any competition for food between the two species, it is likely to be at its most intense at this time when food is shortest, he 
nonetheless congluded that widespread empetition is qunlikely gta occun

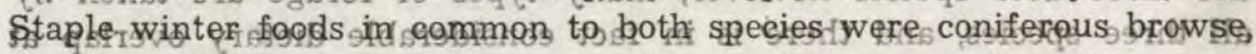
dywarf + shrubs, fruits bramble $_{9}$ gose and $\mathrm{ivy}_{3}$ but, there are clear distinctions

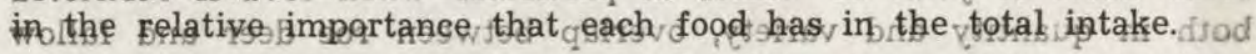

Apparent overlap in any case is clearly reduced when more than one resource dimension is considered. Differences between the Forest's herbivores in asie of habitat and time effectively combine to reduce the effects of high dietary overlap, with combined overlaps falling in most cases to values of $0.4,0.5$ or below - values equivalent to those reported by Leuthola (1976) "fổ niche overlâp over three dimensions amongst browsing ungulates in East Africa, Eninge

Analysis in the current study is still restricted: considering, like Leuthold, only three nicheedimensions; were more resources taken into accouffnt doubtless residual overlap would be still further reduced. In addition, therenare a number of factors which cannot fully be taken into account in such formal analyses, even if the number of resource dimensions examined were increased. Analyses of overlap presented here suggest high theoretical overflap between fallow" deer and sika in terms of both habitat use and diet. Yet in practice, interaction between the two specifes is minimal. As noted on page 272 , while fallow deer are widespread throughout the New Forest area, sika have a very local distribution; indeed they are restricted to small area of the Forest as a whole, an area moreover in which fallow populations, are heavily culled if 2 deliberate attempt to maintain them at very $10 w^{-1}$ density. In practice therefore, high potential overlap revealed from autecological analyses of use of habitat, forage and time is flot realised in practice because the species are geographically isolated, This is a particularly extreme example but a similar principle applies, although at- a more subtle level, in other cases.

Thus results suggest extremely high ${ }_{0}$ overlap between the ${ }_{b}$ cattle and ponies of the Nêt Forest in terms of habitát use: an overlap not unexpected since both species fayour the improved grasslands of the Forest (Table 1). However there are minor differenees in relative use of the different types of grasslands, such that ponies make more use than do cattle of 'stream edges and âcid grassiands while cattle show higher use of grasslands improved by timing or reseeding. Such differences are taken into aceount in the caleulation of overlap indices -

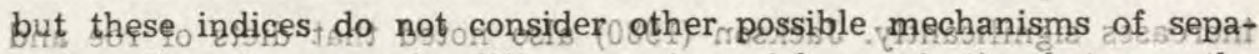
fation. Thu $\mathrm{S}$ for example a $_{9}$ differences in social-organisation between the fibrongly herding cattle and the essentially individualistic ponies mean

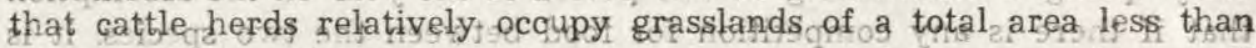
10 ha. whatever the grassland type $T$ because such areas are top small 
to support the eomplete herd; such areas are used predominantly by poz nies 5 and thus some geographical separation is achieved even within use of o single vegetational community $_{1}$ Even where the animals do co-occur on a single common area, separation in habitat use may still be achieved beyond that suggested by the figures of Tables 4 and 6 :

be The most detailed information available on this spatial segregation within communities comes from the Forest grasslands and partigularly on reseeded lawns. In these areas it is clear that cattle and ponies feed in lando occupy distingt areas on the lawns m and that these areas differ

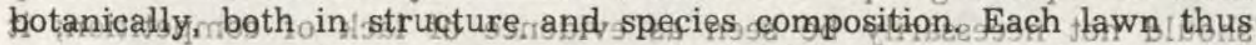
eomprises $\mathrm{a}_{2}$ mosaic of distinct patches (which ${ }_{3}$ we $_{3}$ term "short grass" $_{3}$

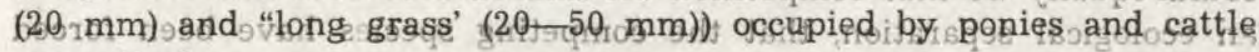

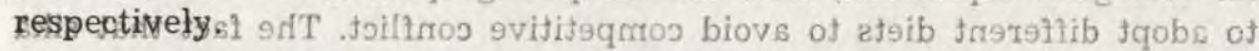

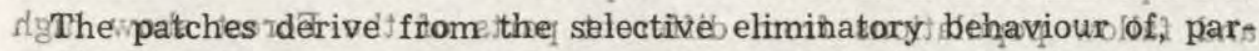

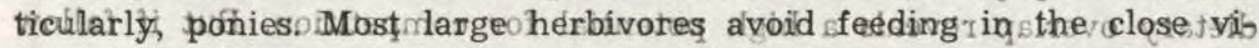
einity of their lown fresh dung an adaptation presumed to reduce the sisk 9 of tparasitic nreinfestationolift an lanimal retitrns to igraze an ared on which dung has been deposited only after luavenisiderable period (during which the dung has largely l degayed) the risk of increasing its permanent parasitio burden to ynaceeptable I levels is considerably reduced Horses ane partioularly "hygienic"; in this regard and 8 recognise specifie datrine lareas within their range oto which they move to defaecate. Sueh behaviour is a well knqwn feature of horses in pasture-

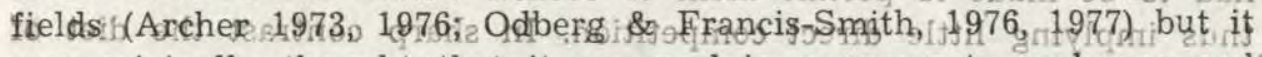
was originally thought that it accurred in response to enclosure and would not be shown by freetranging horses in areas sugh as the New Forest. Edwards and Hollis (1982) have chearly demonstrated however that a mosaic of "latrine"' and "non+latrine" areas does develop on New Forest lawns in response to the same pattern of selective feeding and dunging in the free-ranging ponies of gur studies. ro faiw ggnsio alf to 2) When feeding on lawns, many animals move of $\mathrm{f}$ the area into adjacent vegetation byypes of defaeceate? Towever, thisb is inot ralways possible; and other latine areas are defined within the grassland eommunity itself. Since the animals will not feed in these latrine patches, the grass grows longēr in these areas (ailed by thé) fáct that the latrines

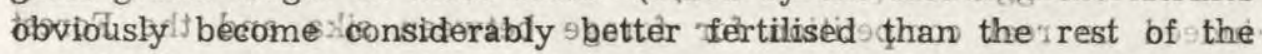
sward). Thus a pattern is established, of ponies feeding on "short grass" patches (which are cropped as close as their teeth will allow) and defaecating in "dong grass"', Since the mechanies of the way in which cattle olatain their food prevents them from feeding on very short grass, cattle pn these same communities are forced to restrict their feeding activity to the "long grass" patches on the lawn. Cattle, unlike ponies, defaecates. 
so to speak at random; since, however, they spend almost all their time in "long-grass" areas, their faeces remain in these patches - and the mosaic is maintained. As a result, use of grasslands is divided, with cattle occupying and feeding within "long grass" areas and ponies feeding on "short grass" patches (see Edwards \& Hollis, 1982).

Further, these analyses of overlap should in any case be interpreted with caution. High overlap does not necessarily imply competition; indeed almost by definition if high overlap is observed the animals must be exploiting super-abundant resources. By converse, low overlap should not necessarily be seen as evidence of lack of competition; it could equally be that competition for shared resources has resulted in an ecological separation, that the competing species have been forced to adopt different diets to avoid competitive conflict. The fact that sika and fallow populations from different parts of the Forest show high dietary overlap reveals a high potential for competition. But if fallow deer were allowed to establish in the sika areas it is probable that analyses of the diet of that particular fallow population would reveal a great reduction in overlap.

In fact the diets of horses, cattle, roe and fallow deer in the New Forest are much as would be expected elsewhere, (see for example: Gates 1982 (Exmoor ponies); Chapman \& Chapman 1975 (fallow); Hosey, 1974; Johnson 1984 (roe)), suggesting that few "adjustments" have had to be made to permit them to coexist within the Forest - and thus implying little direct competition. In sharp contrast the diet of New Forest sika differs markedly from what they appear to eat when allowed to "do what they want" in isolation. Sika in Dorset and five major forests in Scotland all have much the same diet (Mann 1983). Only in the New Forest does the diet seem to change, with increased intake of browse, and lower reliance on grasses. Nor is the direction of the change what one might expect in terms of the difference in habitat: the sika deer of Dorset and Scotland are animals of coniferous plantation and heathland; the New Forest offers a wider diversity of vegetation-types with, in principle, better opportunities of grazing Such an unexpected shift in diet may well then be the result of competition and it is suggested (Mann 1983) that in the New Forest there may indeed be real competition for forage between sika and the Forest ponies.

Such suggestions of competitive interaction are purely inductive and anecdotal. More objective support of such interaction may be adduced from consideration of Levins' asymmetric index of niche overlap. Although interpretation of this index in itself is less straightforward than the symmetric index of Pianka on which this paper is primarily based, 
nevertheless the direction of potential competition may be inferred from the relative asymmetry of the indices calculated for a given species pair. In this case it is clear that competition for winter food between roe and fallow is indeed not likely to be severe, but that there is some support for our suggestion that New Forest fallow and sika may indeed be influenced by dietary competition with both ponies and cattle.

\section{REFERENCES}

1. Archer M., 1973: Variations in potash levels in pastures grazed by horses; a preliminary communication. Equine Veterinary Journal, 5: 45-46.

2. Chapman D. I. \& Chapman N., 1976: The Fallow Deer. Terence Dalton: Suffolk, $271 \mathrm{pp}$.

3. Edwards P. J. \& Hollis S., 1982: The distribution of excreta on New Forest grasslands used by cattle, ponies and deer. J. appl. Ecol., 19: 953-964.

4. Gates S., 1982: The Exmoor Pony: A wild animal? Nature in Devon, 2: 7-30.

5. Hofmann R. R., 1982: Morphological classification of sika deer within the comparative system of ruminant feeding types. Deer, 5: 252-253.

6. Hofmann R. R. \& Stewart D. R. M., 1972: Grazer or browser a classification based on the stomach structure and feeding habits of East African ruminants. Mammalia, 36: 226-240.

7. Hofmann R. R., Geiger G. \& Konig R., 1976: Vergleichend-anatomische Untersuchungen an der Vormagenschleimhaut von Rehwild (Capreolus capreolus) und Rotwild (Cervus elaphus). Zeitschr. Säugetierk., 41: 167-193.

8. Horwood M. T. \& Masters E. H., 1970: Sika Deer. British Deer Society: Reading. $30 \mathrm{pp}$.

9. Hosey G. R., 1974: The food and feeding ecology of roe deer. Ph. D. thesis, University of Manchester.

10. Jackson J. E., 1974: The feeding ecology of Fallow deer in the New Forest, Hampshire. Ph. D. thesis, University of Southampton.

11. Jackson J. E., 1977: The annual diet of the Fallow deer (Dama dama) in the New Horest, Hampshire, as determined by rumen content analysis. J. Zool. (Lond.), 181: 465-473.

12. Jackson J. E., 1980: The annual diet of the roe deer (Capreolus capreolus) in the New Forest, Hampshire, as determined by rumen content analysis. J. Zool. (Lond.), 192: 71-83.

13. Johnson T. H., 1984: Habitat and Social Organisation of Roe deer (Capreolus capreolus). Ph. D. thesis, University of Southampton.

14. Leuthold W., 1978: Ecological separation among browsing ungulates in Tsavo East National Park, Kenya. Oecologia, 35: 241-252.

15. Levins R., 1968: Evolution in Changing Environments. Princeton University Press.

16. Mann J. C. E., 1983: The Social Organisation of Ecology of the Japanese Sika deer (Cervus nippon) in Southern England. Ph. D. thesis, University of Southampton.

17. May R. M., 1976: Mathematical aspects of the dynamics of animal populations. [In: "Studies in Mathematical Biology" ed. Levin, S. A.] American Mathematical Society.

8 - Acta theriologica 


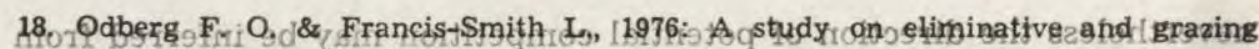

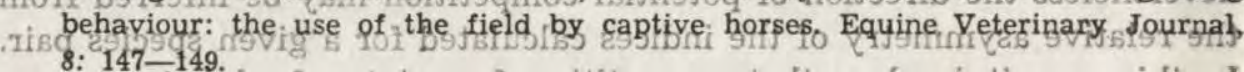

19. ${ }^{7}$ Odberg F. O. \& Francis-Smith K., 1977 : Studies on the formation of ungrazed

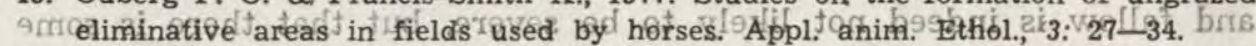

20. Parfitt $\triangle A$., 1986 bcologyl and behaviour//of sallowi deers (Damo dama) in the

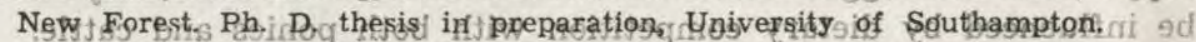

21. Pianka E. R., 1973: The structure of lizard communities. Ann. Rev. Ecol. Syst., 4: $53-74$.

22. Pianka E. R., 1976: Competition and-niche theory. [In: May R. M. ed.: "Theoretical Ecology". Blackwell: Oxford.]

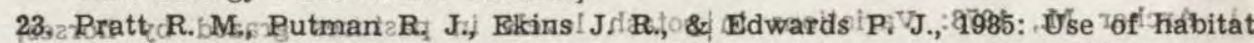
by freeranging, cattle tand ponies/ in the Newit Forrest, nsouthern England. J.

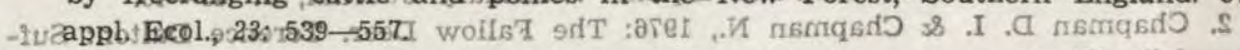

24. Putman R. J., 1986: Grazing in temperate ecosystems: large terbiforelet and

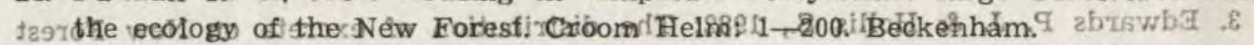

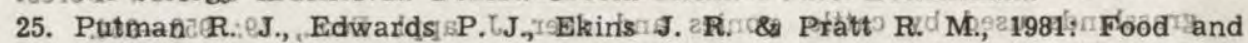
.08 feeding behavior of

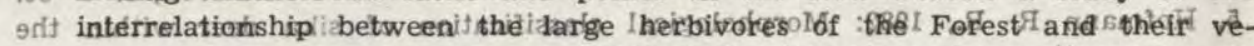

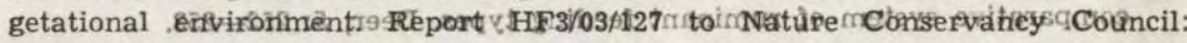

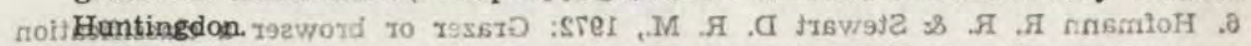

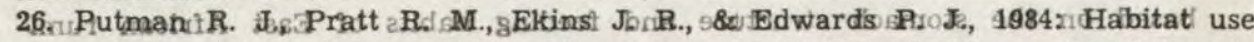
and grazing by free-ranging cattle and poniess, San'd simpaptilupon veégetation in

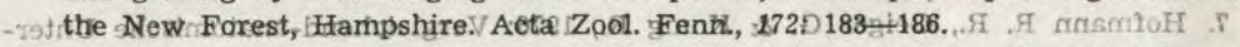

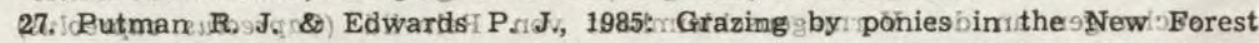
area of Southern [Englandt and their impact on grasslanduvegetation Commission -bsson Horse Production i 36th Ann. Conf: DAAP; Halkidiki, Greece. M boowtio .8

28. Slobodkichoff C. N. \& Schultz W. C., 1980: Measures of niche overlap Eco-

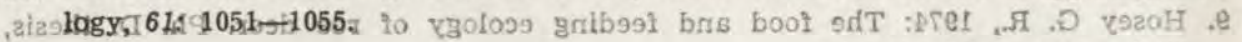
.retagdors $\mathrm{M}$ to vtiatsvinU

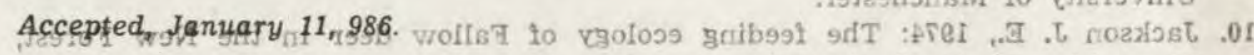

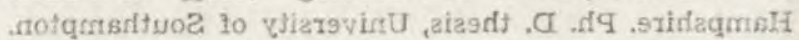

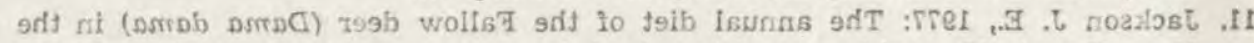

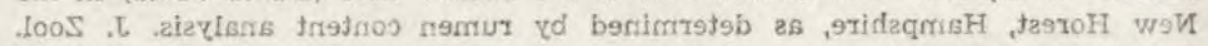
.eTs-cas :I81, (.bcioJ)

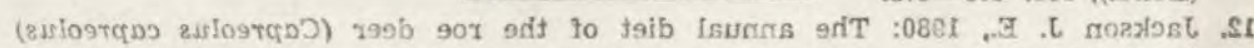

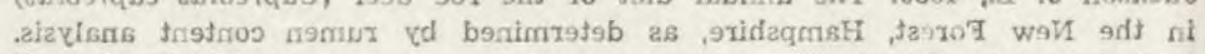
R. J. PUTMAN $.88-15:$ Sel (.broul) . IOOS . $\tau$

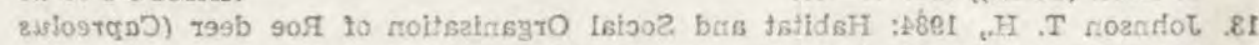

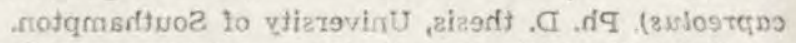

OVSKONKURENCJA I WSPOEISTNIENIE W WAEEOGATUTNROWYM ZESPOLE AI

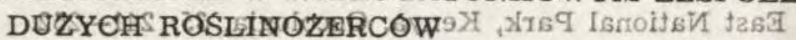

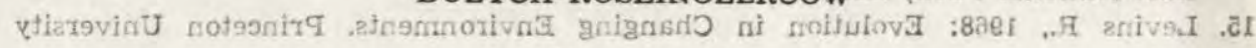
Streszczenie . ฉะ9т

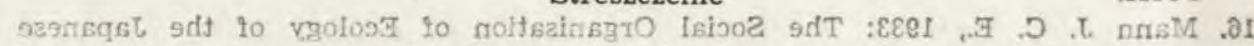

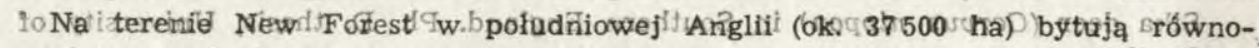
cześnie populacje jelenia szlachetnego, jelenia sika, daniela i sarny,grorał $\llcorner$ bardzo

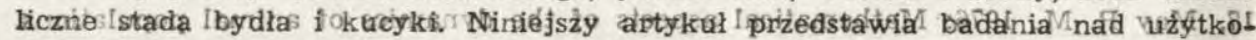

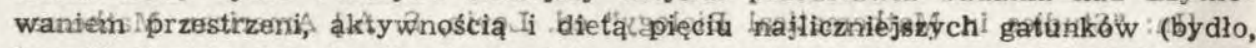
kucyki, daniele, jelenie sika i sarny) i analizuje nakładanie się nisz pomiędzy inimi. Znaczne podobieństwa istniały w użytkowaniu wszystkich zasobów środowiska, 
przy czym największe pokrywanie się występowało w przypadku nisz pokarmowych bydła, kucyków i daniela (Tabele $1-5$ ) i obejmowało $90 \%$ lub więcej czasu w roku. Przy równoczesnym braniu pod uwagę wszystkich użytkowanych zasobów nakładanie się nisz sięga $40-50 \%$. Sugeruje to możliwość istnienia ostrej konkurencji (Tabele 6-8). Dyskutowane są czynniki behawioralne i geograficzne rozdzielenie gatunków jako elementy osłabiające konkurencję. Wyniki wskazują jednak, że na badanym terenie co najmniej w przypadku kucyków i jeleni sika może występować wyraźna konkurencja o pokarm. 